\begin{tabular}{|c|c|c|}
\hline BIODIK & $\begin{array}{c}\text { BIODIK: Jurnal IImiah Pendidikan Biologi } \\
\text { ISSN 2580-0922 (online), ISSN 2460-2612 (print) } \\
\text { Volume 6, Nomor 04, Tahun 2020, Hal. 570-583 } \\
\text { Available online at: } \\
\text { https://online-journal.unja.ac.id/biodik }\end{array}$ & BIODIK \\
\hline
\end{tabular}

Research Article

open 2 Access

\title{
Analisis Lembar Kerja Siswa Praktikum Biologi SMA Pada Materi Uji Kandungan Zat Makanan
}

\section{(Analysis of Student Worksheets of Biology Practicum in High School on Subject Matter Test Food Content)}

Frima Harsawati', Sri Anggraeni, Bambang Supriatno

"Program Studi Pendidikan Biologi, Sekolah Pascasarjana, Universitas Pendidikan Indonesia

Jalan Setiabudi No. 229 Bandung

"Email : fharsawati@gmail.com

\begin{tabular}{|c|c|}
\hline Informasi Artikel & ABSTRACT \\
\hline $\begin{array}{l}\text { Submit: } 02-06-2020 \\
\text { Diterima: } 15-09-2020 \\
\text { Dipublikasikan: } 21-12-2020\end{array}$ & $\begin{array}{l}\text { This study aims to provide an overview of student worksheet on practicum used in } \\
\text { schools. the research method used was qualitative descriptive method and the } \\
\text { sample were } 5 \text { student worksheets selected using a purposive sampling. The } \\
\text { research instrument used is conceptual analysis and practical analysis using } \\
\text { instrument form analysis of laboratory activities and analysis of knowledge } \\
\text { construction based on the scoring table of Diagram Vee adapted from Novak \& } \\
\text { Gowin (1984). The results showed that most of the student worksheet test of food } \\
\text { content did not reach the demands of Basic Competence. This can be seen from the } \\
\text { conceptual analysis. The cognitive level that arises in practicums is only to } \\
\text { remember. Then for the practical analysis of the Test Food Content worksheet that is } \\
\text { analyzed is not yet relevant to the demands of basic competencies. While the } \\
\text { knowledge construction analysis using the Novak \& Gowin instrument shows that } \\
\text { most procedural steps can be done but are less relevant to the purpose of the } \\
\text { practicum, do not bring up the object / event in accordance with the focus question, } \\
\text { practicum questions in student worksheets are largely unanswered based on the } \\
\text { results of laboratory activities, not lead to the formation of knowledge claims and less } \\
\text { help students in linking the knowledge they have with the facts observed. } \\
\text { Keywords: student worksheets, basic competencies, test food content practicum. }\end{array}$ \\
\hline Penerbit & ABSTRAK \\
\hline $\begin{array}{l}\text { Program Studi Pendidikan } \\
\text { Biologi, Fakultas Keguruan dan } \\
\text { Ilmu Pendidikan, Universitas } \\
\text { Jambi-Indonesia }\end{array}$ & $\begin{array}{l}\text { Penelitian ini bertujuan memberikan gambaran lembar kerja siswa pada praktikum } \\
\text { yang digunakan di sekolah. Metode penelitian yang digunakan adalah metode } \\
\text { penelitian deskriptif kualitatif dengan sampel penelitian berjumlah } 5 \text { LKS yang dipilih } \\
\text { dengan menggunakan teknik purposive sampling. Instrumen penelitian yang } \\
\text { digunakan yaitu analisis konseptual dan analisis praktikal menggunakan instrumen } \\
\text { form analisis kegiatan laboratorium dan analisis konstruksi pengetahuan berdasarkan } \\
\text { tabel penskoran Diagram Vee yang diadaptasi dari Novak \& Gowin (1984). Hasil } \\
\text { penelitian menunjukkan bahwa sebagian besar LKS uji kandungan zat makanan } \\
\text { tidak mencapai tuntutan Kompetensi Dasar. Hal tersebut dapat dilihat dari analisis } \\
\text { konseptual Tingkat kognitif yang muncul pada praktikum hanya mengingat saja. } \\
\text { Kemudian untuk analisis praktikal LKS Uji Makanan yang dianalisis belum relevan } \\
\text { dengan tuntutan kompetensi dasar. Sedangkan analisis konstruksi pengetahuan } \\
\text { menggunakan instrumen Novak \& Gowin menunjukkan Sebagian besar langkah } \\
\text { prosedural dapat dikerjakan namun kurang relevan dengan tujuan praktikum, tidak } \\
\text { memunculkan object/event yang sesuai dengan pertanyaan fokus, Pertanyaan } \\
\text { praktikum pada LKS sebagian besar tidak dapat terjawab berdasarkan data hasil } \\
\text { kegiatan laboratorium, tidak mengarahkan pada pembentukkan knowledge claim } \\
\text { serta kurang membantu siswa dalam mengaitkan pengetahuan yang telah dimilikinya } \\
\text { dengan fakta yang diamati. } \\
\text { Katakunci: LKS, kompetensi dasar, Praktikum uji kandungan zat makanan }\end{array}$ \\
\hline
\end{tabular}


This BIODIK : Jurnal IImiah Pendidikan Biologi is licensed under a CC BY-NC-SA (Creative Commons Attribution-ShareAlike 4.0 International License)

\section{PENDAHULUAN}

Pada Revolusi Industri 4.0 di abad ke-21, harapan terhadap siswa telah berubah. Saat ini ada kebutuhan untuk individu yang tidak hanya memiliki pengetahuan teoritis, namun juga memiliki keterampilan untuk dapat menerapkan pengetahuan teoritis yang mereka peroleh, yang dikenal dengan keterampilan abad ke-21. Dalam hal ini, teknologi telah memainkan peran yang cukup penting dalam memperoleh keterampilan ini. Terdapat beragam definisi tentang keterampilan abad ke-21, namun memiliki kesamaan-kesamaan yaitu mencakup keterampilan berpikir kritis, pemecahan masalah, kolaborasi, komunikasi, dan 5 kreativitas. (Zubaidah, 2019)

Keterampilan abad 21 bisa diperoleh dari Pembelajaran sains di laboratorium yang merupakan suatu kegiatan kompleks yang mengintegrasikan hands-on dan minds-on, sehingga kegiatan laboratorium atau kerja praktek memiliki berbagai tujuan. Hal ini sejalan dengan tujuan pendidikan sains sekolah (NSES), yaitu menciptakan siswa terdidik yang mampu untuk melakukan percobaan dengan benar dan terdorong untuk mengetahui dan memahami tentang alam, menggunakan proses-proses ilmiah dan prinsip-prinsip yang tepat dalam membuat keputusan personal. Menggunakan kemampuan intelegensinya dalam diskusi dan debat mengenai materi ilmiah dan teknologi, serta meningkatkan produktivitas ekonominya melalui penggunaan pengetahuan, pemahaman dan ketrampilan ilmiah yang dimiliki dalam karirnya. Sementara menurut Permen DikNas No. 22 Tahun 2006; sains atau IImu Pengetahuan Alam (IPA) berkaitan dengan cara mencari tahu (inquiry) tentang alam secara sistematis, sehingga IPA bukan hanya sebagai penguasaan kumpulan pengetahuan yang berupa fakta, konsep atau prinsip saja, tetapi juga merupakan suatu proses penemuan. Berdasarkan tujuan yang tertuang tersebut tampak bahwa hakekat pendidikan sains merupakan suatu proses yang aktif, baik fisik maupun mental, melalui kegiatan inkuiri (inquiry). Oleh karena itu kalau pembelajaran sains hanya diukur penguasaan materinya saja, sangatlah keliru (Supriatno, 2013).

Sebagai upaya untuk melaksanakan kegiatan laboratorium secara berkesinambungan, maka dalam pembelajaran sains, dapat dilakukan dengan mengintegrasikan kegiatan laboratorium tersebut dalam proses pembelajaran. Hal tersebut juga dapat mengarahkan proses aktif siswa selama proses pembelajaran, melatih kemampuan inquiri, mengumpulkan data dan fakta, sistematis dalam mendeskripsikan objek, membuktikan teori dan prinsip, mengajukan pertanyaan, melakukan discovery, dan mengomunikasikan hasil temuan. Menurut Supriatno (2009) kegiatan laboratorium dapat memberikan kesan yang utuh dan lebih bermakna kepada siswa, karena selama pembelajaran mereka cenderung melibatkan berbagai indera seperti penglihatan, penciuman, pendengaran, peraba dan pengecapan. Kegiatan laboratorium yang dilakukan oleh siswa umumnya 
mengacu pada suatu Desain Kegiatan Laboratorium (DKL). Desain kegiatan ini yang berisi sejumlah langkah kerja operasional dapat memandu praktikan dalam melaksanakan kegiatan di laboratorium. DKL dapat diwujudkan ke dalam bentuk LKS maupun terintegrasi ke dalam buku paket. Menurut Rustaman \& Wulan (2007) LKS (Lembar Kerja Siswa) merupakan salah satu media pembelajaran yang berisi petunjuk untuk melaksanakan kegiatan laboratorium. Suatu LKS yang baik hendaknya mencakup beberapa aspek, yaitu (1) tujuan kegiatan, (2) pendahuluan (berupa dasar teori) (3) alat dan bahan, (4) prosedur kerja, (5) cara perangkaian alat, (6) interpretasi data hasil pengamatan, (7) analisis data dan (8) simpulan (A. Rustaman \& Wulan, 2007).

Berkaitan dengan aspek-aspek tersebut, Supriatno (2007) mengkaji 46 sampel LKS Biologi, yang hasilnya mengungkap bahwa sebagian besar pembuat LKS tidak atau belum melakukan uji coba LKS tersebut dari segi proses ataupun produk yang dihasilkan. Temuan mengungkap banyaknya langkah kerja yang kurang terstruktur dan tidak mengarahkan untuk memperoleh data yang benar. Selain itu, hasil uji keterlaksanaan prosedur kerja (Supriatno, 2009) menunjukkan bahwa, langkah kerja yang dapat dikerjakan dan menghasilkan data yang benar, tuntas dalam analisis serta dapat digunakan untuk membuat simpulan hanya berkisar $24 \%$. Sisanya sebanyak $76 \%$ bermasalah dalam: (1) tidak terstrukturnya langkah kerja, (2) kesulitan dalam eksekusi langkah kerja (3) kekakuan tabel data dan menimbulkan hasil yang miskonsepsi, (4) membutuhkan waktu yang lama, dan (5) ketidaktuntasan.

Pelaksanaan Kurikulum 2013 mengharapkan agar setiap siswa dapat memenuhi standar kompetensi lulusan dalan hal sikap, keterampilan dan pengetahuan. Sehingga diharapkan dalam pembelajaran IPA di kelas guru dapat menciptakan pembelajaran yang bermakna dan membekali siswa kecakapan hidup (life skill). Menurut Bioscience (2010) praktik dan kerja lapangan dapat memberi kita rasa bagaimana rasanya menjadi seorang ilmuwan dan peneliti dan pengalaman langsung dari teori yang telah Anda pelajari dalam kuliah dan melalui bacaan Anda. Mereka memberi Anda kesempatan untuk mengembangkan analisis data, kerja kelompok komunikasi, dan keterampilan lain yang tidak akan Anda dapatkan dari kuliah. Praktik di universitas atau perguruan tinggi seringkali akan sangat berbeda dari yang Anda alami di sekolah: mereka mungkin lebih panjang, berakhir (mungkin tidak ada jawaban "benar"), melibatkan peralatan yang lebih kompleks dan memerlukan pengukuran dan pencatatan yang lebih akurat. Maka dari mengapa praktikum itu menjadi penting untuk dilakukan karena memberikan pengalaman langsung dari teori yang telah dipelajari. Menurut Akuma (2017) Jenis pekerjaan praktis ini terdiri dari pengalaman di mana peserta didik secara kolaboratif memanipulasi kombinasi peralatan dan bahan pendidikan sains berbasis tangan dan I atau berbasis komputer, atau kumpulan data yang ada, untuk lebih memahami dunia alami ketika mereka terlibat dalam praktik ilmiah melalui pertanyaan terstruktur, terarah, atau terbuka.

Salah satu metode pembelajaran yang sesuai dengan Kurikulum 2013 dan dapat meningkatkan hasil belajar siswa dalah metode praktikum. Melalui kegiatan 
praktikum siswa dapat dilatih berpikir ilmiah melalui langkah-langkah kerja ilmiah. Hal ini sesuai dengan pendapat Rustaman dkk, (2002) yang menyatakan bahwa dalam pendidikan IPA, kegiatan laboratorium merupakan bagian integral dari kegiatan belajar mengajar. Dengan praktikum dapat diperoleh jawaban tentang: bagaimana kita tahu bahwa itu benar? Apakah yang akan terjadi? Terdiri dari bahan apa saja? Secara teliti dan ilmiah (Surakhmad, 1994 dalam Sriyati: 2013). Pertanyaan untuk guru biologi, kemudian, adalah bagaimana merancang 'praktis' (yaitu kegiatan praktis yang dilakukan dalam pelajaran biologi) yang mempromosikan 'mind-on' keterlibatan dengan mengatasi tuntutan pembelajaran dalam domain ide-yaitu, jenis apa perancah dapat mempromosikan pembelajaran dari pekerjaan praktis dalam domain ide (Philip, 2015).

Praktikum merupakan kegiatan pembelajaran yang bertujuan agar siswa mendapat kesempatan untuk menguji dan mengaplikasikan teori dengan menggunakan fasilitas laboratorium maupun di luar laboratorium. Praktikum dalam pembelajaran Biologi merupakan metode yang efektif untuk mencapai tujuan pembelajaran (Rustaman, 2005:135). Sehingga pembelajaran praktikum memiliki peran dalam pengembangan keterampilan proses sains siswa. Penerapan keterampilan proses sains sekaligus pengembangan sikap ilmiah yang mendukung proses pengetahuan dalam diri siswa sangat dimungkinkan dalam kegiatan praktik, sehingga dalam pembelajaran IPA praktikum memiliki kedudukan yang amat penting. Abrahams dan Millar (2008) menyatakan bahwa meskipun kerja praktek adalah alat yang agak efektif untuk membuat siswa mengingat aspek-aspek praktis dari eksperimen, ide-ide di balik fenomena jarang dipelajari dan bahkan lebih sering diingat kemudian. Namun, mereka terus berpendapat bahwa guru mengharapkan siswa untuk belajar ide-ide ilmiah dari kerja praktek. Kontradiksi yang jelas antara hasil belajar dan hasil aktual ini adalah jantung dari masalah dalam pengajaran sains praktis. Millar (2004) menegaskan bahwa diskusi yang mengikuti setiap kegiatan praktis sangat penting untuk mengembangkan pemahaman, dan bahwa keduanya sangat erat terkait sehingga tidak masuk akal untuk memisahkan mereka. Millar menambahkan bahwa peran kerja praktek dalam pengajaran dan pembelajaran konten sains adalah untuk membantu siswa untuk membuat hubungan antara dua "domain" pengetahuan seperti yang ditunjukkan pada Gambar 1

Figure 1: Practical work: linking two domains of knowledge (Millar, 2004, p.8) Kegiatan praktikum penting dilakukan, karena dengan melakukan kegiatan praktikum siswa lebih memahami dan lebih tahu tentang konsep materi yang sedang dipelajari. Menurut Abraham \& Reiss (2010) kerja praktek selalu akan memiliki peran kunci dalam pengajaran sains. Tantangannya adalah untuk terus menemukan cara 
untuk menjadikannya strategi pengajaran dan pembelajaran seefektif mungkin, sambil tetap mempertahankan nilai afektif yang jelas dan menyegarkan. Dalam society of biology (2010) Masyarakat Biologi percaya bahwa penting untuk mendukung dan mempromosikan kerja praktis dalam sains karena: Menstimulasi kreativitas, keingintahuan dan pemikiran kritis, Menopang dan mengilustrasikan konsep, pengetahuan, dan prinsip-prinsip, Mendorong keterlibatan siswa dengan metode ilmiah, Mendorong pembelajaran aktif dan pemecahan masalah, Memungkinkan kerja kolaboratif, Memberikan peluang untuk mengumpulkan dan menganalisis data dan menerapkan keterampilan matematika.

Domain kognitif berhubungan dengan sikap siswa terhadap pengetahuan mereka tentang pekerjaan praktis dan apa yang mereka pikir mereka ketahui dan percayai tentang pekerjaan praktis. Sementara siswa dapat mengklaim bahwa mereka menyukai pekerjaan praktis karena mereka berpikir bahwa itu membantu mereka mempelajari klaim semacam itu tidak harus tentang kenyataan sebenarnya dari pembelajaran itu, yaitu apakah mereka benar-benar belajar secara efektif dari melakukan pekerjaan praktis, tetapi lebih merupakan pernyataan keyakinan pribadi (Sharpe, 2019).

Relevansi kegiatan praktikum dengan kurikulum saling berkaitan erat, karena memang tuntutan kurikulum harus meningkatkan skills keterampilan. Untuk mendidik anak bagaimana melatih logikanya, sejauh ini relevansi kegiatan praktikum dengan kurikulum masih bisa dikatakan belum sesuai dengan capaian yang diharapkan. Tujuan praktikum yang dilakukan ini disesuaikan dengan kompetensi dasar yang diharapkan dalam Biologi, untuk mencapai itu procedur yang dilakukan harus manjawab tujuan yang mengandung focus question (investigasi), dan objek atau event melahirkan fakta yang ditansformasikan dan di interpretasikan menjadi sebuah knowledge claim (kesimpulan). Dalam Millar (2001). Tujuan dari kerja praktek ini adalah untuk membantu siswa memperhatikan suatu fenomena, mungkin untuk melihatnya secara lebih rinci daripada sebelumnya, dan mungkin untuk mengingatnya setelahnya. Beberapa praktik memiliki tujuan yang terkait erat dengan hal ini, yaitu untuk membantu siswa mempersempit penggunaan istilah (seperti melarutkan) atau untuk mempelajari yang baru, dan Menurut Banu (2011) banyak guru sains percaya itu kerja praktek dapat memaparkan siswa pada data sensorik yang membantu mereka membangun ilmiah konsep. Klise "Saya lakukan dan saya mengerti" sering digunakan untuk mendukung penggunaan praktis bekerja dalam pengajaran sains. Dan dalam good practical science Hands on practical work bagian terpenting dari ilmu pembelajaran, itu juga mengembangkan keterampilan dan sikap yang berharga dan adalah salah satu geteways terhadap ketenagakerjaan.

Pengelolaan dan keterlaksanaan saat praktikum masih banyak yang harus di tingkatkan guna memaksimalkan kegiatan praktikum itu sendiri. Akan tetapi di lapangan banyak LKS yang tidak sesuai dengan tuntutan kompetensi dasar, banyak procedur LKS yang membingungkan dan rancu tidak sesuai dengan tujuan praktikum, alat dan bahan yang kuang lengkap atau tidak sesuai dengan standar sekolah, pertanyaan-pertanyaan dalam LKS yang tidak menuntun tujuan untuk

\section{Harsawati, dkk}


merekonstruksi konsep, banyak LKS praktikum yang tidak bermakna, banyak LKS yang membuat frustasi Guru seperti dalam festile (2017). Mereka semakin frustrasi dengan "terlalu banyak buku sains" yang "memiliki sudut pandang yang berbeda". Kerja praktek merupakan aktivitas mengajar dan belajar yang melibatkan siswa dalam observasi, manipulasi objek dan bahan-bahan nyata (Millar, 2004). Menurut Novak (1998) konstruksi pengetahuan dimulai dengan observasi terhadap objek atau peristiwa. Karakteristik objek/even sebagai fakta hasil obervasi biasanya dinyatakan sebagai data kualitatif dan atau kuantitatif. Proses kontruksi pengetahuan dimulai dengan mencoba mencari hubungan antara fakta yang ada dengan pengetahuan yang sudah dimiliki. Hakekatnya ini adalah aktivitas nalar (minds-on), berupa interaksi kognitif antara domain riil yang diwakili oleh data faktual dengan domain pikiran (pengetahuan awal) sehingga memungkinkan penguatan atau kontruksi pengetahuan baru (supriatno, 2018).

Penelitian yang dilakukan adalah menganalisis konseptual, analisis praktikal, analisis konstruksi pengetahuan, kesimpulan analisis berdasarkan instrument form analisis kegiatan laboratorium. Dan pada penelitian kali ini akan dikaji lagi lebih dalam mengenai relevansi LKS dengan Standar Kompetensi dan Kompetensi Dasar. Aspek desain kegiatan praktikum yang dianalisis dalam penelitian ini lebih luas lagi, diantaranya terdiri atas aspek tujuan praktikum, pertanyaan fokus, langkah prosedural, objek/peristiwa utama, pencatatan/transformasi data hasil praktikum, pertanyaan praktikum, dan knowledge claim yang terbentuk. Berkenaan dengan masalah yang telah dipaparkan, peneliti bermaksud untuk melakukan penelitian mengenai analisis relevansi lembar kerja siswa terhadap Kompetensi Dasar pada praktikum uji makanan.

\section{METODE PENELITIAN}

Metode penelitian yang digunakan dalam penelitian ini adalah metode deskriptif kualitatif, Penelitian ini bertujuan untuk menganalisis lembar kerja siswa yang biasa digunakan di sekolah, maupun desain kegiatan praktikum yang dibuat oleh guru biologi pada praktikum uji makanan berdasarkan analisis konseptual, procedural, dan konstruksi pengetahuan. Penelitian ini mengikuti tahapan ANCOR ( Analisis, Coba, Rekonstruksi) yang dikembangkan oleh Supriatno (2013). Populasi penelitian yang digunakan di dalam penelitian ini adalah lembar kerja siswa SMA kelas XI yang digunakan oleh guru dalam pelaksanaan kegiatan laboratorium. Sampel dalam penelitian ini adalah lembar kerja siswa praktikum uji makanan kelas XI yang digunakan dalam pembelajaran di sekolah. Teknik sampling yang digunakan yaitu purposive sampling untuk LKS dari SMA Negeri dan lima LKS saja yang di analisis.

Data dikumpulkan dengan menggunakan dua instrumen yang telah dikembangkan oleh peneliti yang digunakan untuk menganalisis relevansi komponen-komponen LKS dengan Kompetensi Dasar. Langkah pertama yang dilakukan adalah mengumpulkan lembar kerja siswa kelas XI semester pada praktikum uji makanan berdasarkan kurikulum 2013 Sekolah Menengah Atas Negeri yang di gunakan. 
Langkah kedua, yaitu mengumpulkan beberapa LKS yang digunakan,. Dari lembar kerja siswa yang didapatkan, dilakukan pemilihan LKS berdasarkan konsepnya yaitu praktikum uji makanan dan LKS yang digunakan sebagai rujukan kegiatan laboratorium di sekolah (purposive sampling). Hasil yang diperoleh, yaitu lima LKS konsep pencernaan makanan. Lembar kerja siswa yang dianalisis berasal dari LKS yang dibuat oleh penerbit.

Tahap selanjutnya adalah melakukan uji coba pada lembar kerja siswa yang didapat sesuai prosedur tanpa ada perubahan. Kegiatan uji coba lembar kerja siswa dilakukan di laboratorium fisiologi universitas pendidikan indonesia. Kemudian dari hasil uji coba, peneliti memasukkan data ke dalam dua instrumen yang telah dikembangkan dan dipaparkan sebelumnya.

\section{HASIL DAN PEMBAHASAN}

Berdasarkan hasil penelitian ini diperoleh lembar kerja siswa yang tidak relevan dengan tuntutan kompetensi dasar pada kurikulum 2013. Analisis relevansi lembar kerja siswa terhadap Kompetensi Dasar pada praktikum uji makanan akan dijabarkan sebagai berikut.

\section{Relevansi}

Relevansi merupakan tingkat kesesuaian dan hubungan antara lembar kerja siswa (komponen tujuan, pertanyaan fokus, langkah prosedural, objek/peristiwa, record/transformation, pertanyaan praktikum, dan knowledge claims) dengan tuntutan Kompetensi Dasar pada kurikulum 2013. Relevansi tersebut diukur berdasarkan kriteria yang tersedia dalam instrumen penelitian.

\section{Lembar kerja siswa}

Desain kegiatan praktikum merupakan prosedur yang menuntun siswa dalam melaksanakan kegiatan praktikum. Lembar kerja siswa terdiri atas tujuan, pertanyaan fokus, langkah prosedural, objek/peristiwa, record/transformation, pertanyaan praktikum, dan knowledge claims. Desain kegiatan yang dianalisis merupakan lembar kerja siswa yang digunakan dan berasal dari LKS, buku paket biologi SMA atau LKS yang terdapat pada buku paket yang dipakai di sekolah mengenai kegiatan laboratorium uji makanan dan mengacu pada Kurikulum 2013.

\section{Kompetensi Dasar}

Kompetensi dasar yang dimaksud dalam penelitian ini adalah Kompetensi Dasar SMA Kelas XI Semester 2 kurikulum 2013 yaitu 4.7 menyajikan laporan hasil uji zat makanan yang terkandung dalam berbagai jenis bahan makanan dikaitkan dengan kebutuhan energy setiap individu serta teknologi pengolahan pangan dan keamanan pangan.

\section{Instrumen penelitian}

Instrumen yang digunakan dalam penelitian ini adalah: 
a. Analisis kisi-kisi penjabaran Standar Kompetensi (SK) dan Kompetensi Dasar (KD) yang digunakan sebagai panduan dalam menganalisis Lembar Kerja Siswa.

Tabel analisis kisi-kisi penjabaran Standar Kompetensi (SK) dan Kompetensi Dasar (KD) yang digunakan sebagai panduan dalam menganalisis lembar kerja siswa pada Tabel 1.

\begin{tabular}{|c|c|c|}
\hline Kompetensi Dasar & Indikator & Tujuan Pembelajaran \\
\hline $\begin{array}{l}.7 \text { Menyajikan } \\
\text { laporan hasil uji } \\
\text { zat makanan } \\
\text { yang terkandung } \\
\text { dalam berbagai } \\
\text { jenis makanan } \\
\text { dikaitkan dengan } \\
\text { kebutuhan } \\
\text { energi setiap } \\
\text { individu serta } \\
\text { teknologi } \\
\text { pengolahan } \\
\text { pangan dan } \\
\text { keamanan } \\
\text { pangan. }\end{array}$ & $\begin{array}{l}\text { M.7.1 Merancang } \\
\text { eksperimen } \\
\text { tentang uji zat } \\
\text { makanan yang } \\
\text { terkandung dalam } \\
\text { bahan makanan. } \\
\text { Mengkomunikasik } \\
\text { an zat makanan } \\
\text { dengan energi } \\
\text { kebutuhan individu, } \\
\text { setiap dan } \\
\text { tekhnologi } \\
\text { pengolahan } \\
\text { pangan } \\
\text { keamanan } \\
\text { pangan. }\end{array}$ & $\begin{array}{l}\text { 4.7.1.2 Setelah siswa melakukan diskusi kelompok tentang } \\
\text { zat-zat makanan yang terkandung dalam makanan, } \\
\text { siswa mampu merencanakan eksperimen tentang uji } \\
\text { zat makanan yang terkandung dalam bahan } \\
\text { makanan. } \\
\text { Setelah siswa melakukan studi literatur tentang } \\
\text { ekperimen uji zat makanan, siswa mampu } \\
\text { merancang eksperimen tentang uji zat makanan } \\
\text { yang terkandung dalam bahan makanan. } \\
\text { Setelah siswa menganalisis hasil data eksperimen, } \\
\text { siswa dapat menghubungkan zat makanan dengan } \\
\text { kebutuhan energi setiap individu, tekhnologi } \\
\text { pengolahan pangan dan keamanan pangan. } \\
\text { 4.1.1.1.5 Setelah siswa mendapatkan hasil analisis data pada } \\
\text { pengamatan uji makanan dan diskusi kelompok, } \\
\text { siswa dapat menyajikan hasil analisis data dan } \\
\text { diskusi kelompok tersebut pada kelompok lain. }\end{array}$ \\
\hline
\end{tabular}

b. Analisis berdasarkan instrument form analisis kegiatan laboratorium

1) Analisis konseptual

Tabel 2 Rekapitulasi Analisis Konseptual LKS

Kesesuaian dengan Kurikulum

\begin{tabular}{|c|c|c|c|c|c|c|c|c|c|c|c|}
\hline \multicolumn{12}{|c|}{ Kesesuaian dengan Kurikulum } \\
\hline & Bagian ini Bertujuan untuk menganali & esua & n kegia & an $\mathrm{Lc}$ & oratoril & $n \mathrm{de}$ & gan kur & ulum & yang be & aku & \\
\hline & \multirow{2}{*}{ Parameter } & \multicolumn{2}{|c|}{ LKS 1} & \multicolumn{2}{|c|}{ LKS 2} & \multicolumn{2}{|c|}{ LKS 3} & \multicolumn{2}{|c|}{ LKS 4} & \multicolumn{2}{|c|}{ LKS 5} \\
\hline & & $\mathrm{Ya}$ & Tidak & $\mathrm{Ya}$ & Tidak & $\mathrm{Ya}$ & Tidak & $\mathrm{Ya}$ & Tidak & $\mathrm{Ya}$ & Tidak \\
\hline 1 & Kesesuaian Konten dengan KD & & $\sqrt{ }$ & & $\sqrt{ }$ & & $\sqrt{ }$ & & $\sqrt{ }$ & & $\sqrt{ }$ \\
\hline 2 & Kesesuaian Kompetensi dengan KD & & $\sqrt{ }$ & & $\sqrt{ }$ & & $\sqrt{ }$ & & $\sqrt{ }$ & & $\sqrt{ }$ \\
\hline 3 & Kesesuaian Judul dengan Kegiatan & $\sqrt{ }$ & & & $\sqrt{ }$ & $\sqrt{ }$ & & $\sqrt{ }$ & & & $\sqrt{ }$ \\
\hline 4 & $\begin{array}{l}\text { Kesesuaian Tujuan dengan Langkah } \\
\text { Kerja }\end{array}$ & $\sqrt{ }$ & & & $\sqrt{ }$ & $\sqrt{ }$ & & $\sqrt{ }$ & & $\sqrt{ }$ & \\
\hline 5 & $\begin{array}{l}\text { Kesesuaian Kegiatan dengan tingkat } \\
\text { kognitif siswa }\end{array}$ & $\sqrt{ }$ & & & $\sqrt{ }$ & & $\sqrt{ }$ & & $\sqrt{ }$ & & $\sqrt{ }$ \\
\hline
\end{tabular}

Berdasarkan tabel di atas dapat disimpulkan bahwa praktikum pada umumnya hanya menuntut menyajikan laporan uji bahan makanan tanpa mengaitkan dengan kebutuhan energy dan teknologi pangan dan keamanan pangan, kesesuaian kompetensi dengan KD tidak sesuai pengembangan KD yang ingin dicapai adalah mengaitkan dengan kebituhan energy dan teknologi pangan juga keamanan pangan, judul praktikum umumnya sudah sesuai dengan langkah kerja, tujuan praktikum umumnya sudah sesuai dengan langkah kerja, Tingkat kognitif umumnya yang dituntut pada lembar kerja siswa SMA masih berada pada tingkatan rendah, pada jenjang SMA tingkat kognitif yang dituntut tidak sesuai dengan kompetensi dasar. tingkat kognitif yang dituntut umumnya lebih dominan pada C1 mengingat, C2 memahami dan C3 menerapkan. Tingkat kognitif dominan yang dituntut pada lembar 
kerja siswa SMA yaitu pengetahuan prosedural kategori C3 menerapkan sedangkan tuntutan pada KD masih C2 menyajikan

\section{2) Analisis Praktikal}

Tabel 3. Rekapitulasi Analisis Praktikal LKS

Analisis Praktikal

\begin{tabular}{|c|c|c|c|c|c|c|c|c|c|c|c|}
\hline & \multirow{2}{*}{ Parameter } & \multicolumn{2}{|c|}{ LKS 1} & \multicolumn{2}{|c|}{ LKS 2} & \multicolumn{2}{|c|}{ LKS 3} & \multicolumn{2}{|c|}{ LKS 4} & \multicolumn{2}{|c|}{ LKS 5} \\
\hline & & $\mathrm{Ya}$ & Tidak & $\mathrm{Ya}$ & Tidak & $\mathrm{Ya}$ & Tidak & $\mathrm{Ya}$ & Tidak & $\mathrm{Ya}$ & Tidak \\
\hline 1 & $\begin{array}{l}\text { Apakah alat-alatnya sesuai } \\
\text { dengan standar/tersedia di } \\
\text { sekolah }\end{array}$ & $\sqrt{ }$ & & $\sqrt{ }$ & & $\sqrt{ }$ & & $\sqrt{ }$ & & $\sqrt{ }$ & \\
\hline 2 & $\begin{array}{l}\text { Apakah bahan praktikum } \\
\text { dapat disediakan dengan } \\
\text { mudah }\end{array}$ & $\sqrt{ }$ & & $\sqrt{ }$ & & $\sqrt{ }$ & & $\sqrt{ }$ & & & $\sqrt{ }$ \\
\hline 3 & $\begin{array}{l}\text { Apakah Langkah- } \\
\text { langkahnya terstruktur }\end{array}$ & & $\sqrt{ }$ & $\sqrt{ }$ & & & $\sqrt{ }$ & & $\sqrt{ }$ & & $\sqrt{ }$ \\
\hline 4 & $\begin{array}{l}\text { Apakah setiap langkah } \\
\text { dapat di eksekusi tanpa } \\
\text { kesulitan }\end{array}$ & & $\sqrt{ }$ & & $\sqrt{ }$ & & $\sqrt{ }$ & & $\sqrt{ }$ & & $\sqrt{ }$ \\
\hline 5 & $\begin{array}{l}\text { Apakah objek fenomenanya } \\
\text { muncul }\end{array}$ & & $\sqrt{ }$ & $\sqrt{ }$ & & $\sqrt{ }$ & & $\sqrt{ }$ & & $\sqrt{ }$ & \\
\hline 6 & $\begin{array}{l}\text { Apakah objek fenomenanya } \\
\text { mudah diamati }\end{array}$ & & $\sqrt{ }$ & & $\sqrt{ }$ & & $\sqrt{ }$ & & $\sqrt{ }$ & & $\sqrt{ }$ \\
\hline 7 & $\begin{array}{l}\text { Apakah ada perekaman } \\
\text { data }\end{array}$ & $\sqrt{ }$ & & & $\sqrt{ }$ & & $\sqrt{ }$ & & $\sqrt{ }$ & & $\sqrt{ }$ \\
\hline 8 & $\begin{array}{l}\text { Bagaimana bentuk } \\
\text { perekaman objek/fenomena }\end{array}$ & $\sqrt{ }$ & & & $\sqrt{ }$ & & $\sqrt{ }$ & & $\sqrt{ }$ & & $\sqrt{ }$ \\
\hline 9 & $\begin{array}{l}\text { Apakah objek fenomena } \\
\text { relevan dengan judul/tujuan }\end{array}$ & & $\sqrt{ }$ & & $\sqrt{ }$ & & $\sqrt{ }$ & & $\sqrt{ }$ & & $\sqrt{ }$ \\
\hline 10 & $\begin{array}{l}\text { Berapa lama waktu yang } \\
\text { digunakan untuk } \\
\text { melaksanakan kegiatan } \\
\text { Praktikum }\end{array}$ & & $\sqrt{ }$ & & $\sqrt{ }$ & & $\sqrt{ }$ & & $\sqrt{ }$ & & $\sqrt{ }$ \\
\hline 11 & $\begin{array}{l}\text { Bagaimana bentuk } \\
\text { perekaman objek/fenomena }\end{array}$ & & $\sqrt{ }$ & & $\sqrt{ }$ & & $\sqrt{ }$ & & $\sqrt{ }$ & & $\sqrt{ }$ \\
\hline 12 & $\begin{array}{l}\text { Apakah objek fenomena } \\
\text { relevan dengan judul/tujuan }\end{array}$ & & $\sqrt{ }$ & & $\sqrt{ }$ & & $\sqrt{ }$ & & $\sqrt{ }$ & & $\sqrt{ }$ \\
\hline
\end{tabular}

Praktikum pada umumnya menggunakan alat-alat yang sesuai dengan standar/tersedia sekolah, Bahan praktikum pada umumnya dapat disediakan dengan mudah, Pada umumnya langkah-langkahnya langkah kerja yang kurang terstruktur dan tidak mengarahkan untuk memperoleh data yang benar, Pada umunnya prosedur yang terlalu banyak untuk makna dari ulangan tidak perlu bahan yang lain diuji dengan reagen yang lain untuk melihat keajegan hasilnya, cukup 4 saja untuk setiap pengujian. Jadi setiap langkah kesulitan dalam mengeksekusi. Pada umumnya objek/fenomenanya dapat muncul, Pada umumnya objek/fenomena mudah diamati, Pada umumnya terdapat perekaman data, Pada umumnya bentuk perekaman objek/fenomena berupa tabel, Pada umumnya Objek/fenomena tidak sesuai dengan judul dan tujuan, harus ada pembandingnya dan harus

\section{Harsawati, dkk}


menggunakan bahan makanan, Pada umumnya tidak ada alokasi waktu yang digunakan untuk melaksanakan kegiatan praktikum, Pada umumnya Tidak ada safety consideration padahal ada hal-hal yang perlu diperhatikan khususnya dalam penggunaan etanol pekat, pembakar spirtus, dan lugol. Pada umumnya prosedur tidak mencapai tujuan karena tidak menghadirkan fakta sehingga tidak bisa ditransformasi dan mengkonstruksi pengetahuan.

\section{3) Analisis konstruksi pengetahuan berdasarkan instrumen Novak \& Gowin}

Tabel 4. Keberadaan Komponen Diagram Vee pada Lima LKS SMA Materi uji makanan

\begin{tabular}{llccccc}
\hline \multirow{2}{*}{ No } & Kode LKS & $\begin{array}{c}\text { Pertanyaan } \\
\text { Fokus }\end{array}$ & $\begin{array}{c}\text { Objek/ } \\
\text { Peristiwa }\end{array}$ & $\begin{array}{c}\text { Teori, Prinsip, dan } \\
\text { konsep }\end{array}$ & $\begin{array}{c}\text { Catatan/ } \\
\text { Transformasi }\end{array}$ & $\begin{array}{c}\text { Klaim } \\
\text { Pengetahuan }\end{array}$ \\
\hline $\mathbf{1}$ & LKS 1 & $\mathrm{V}$ & - & $\mathrm{V}$ & $\mathrm{V}$ & - \\
\hline $\mathbf{2}$ & LKS 2 & $\mathrm{V}$ & - & $\mathrm{V}$ & - & - \\
\hline $\mathbf{3}$ & LKS 3 & $\mathrm{V}$ & $\mathrm{V}$ & $\mathrm{V}$ & $\mathrm{V}$ & $\mathrm{V}$ \\
\hline $\mathbf{4}$ & LKS 4 & $\mathrm{V}$ & - & $\mathrm{V}$ & - & - \\
\hline $\mathbf{5}$ & LKS 5 & $\mathrm{V}$ & - & $\mathrm{V}$ & $\mathrm{V}$ & - \\
\hline
\end{tabular}

Keterangan:

$(V)=$ ada $(-)=$ tidak ada

Tabel 5. Skor Komponen Diagram Vee pada LKS SMA Materi Uji Makanan

\begin{tabular}{|c|c|c|c|c|c|c|c|}
\hline No & Kode LKS & $\begin{array}{c}\text { Pertanyaan } \\
\text { Fokus }\end{array}$ & $\begin{array}{c}\text { Objek/ } \\
\text { peristiwa }\end{array}$ & $\begin{array}{l}\text { Langkah } \\
\text { procedural }\end{array}$ & $\begin{array}{c}\text { Catatan/ } \\
\text { Transformasi }\end{array}$ & $\begin{array}{c}\text { Klaim } \\
\text { pengetahuan }\end{array}$ & $\begin{array}{l}\text { Tota } \\
\text { Skor }\end{array}$ \\
\hline 1 & Lks 1 & 2 & 3 & 2 & 3 & 1 & 11 \\
\hline 2 & Lks 2 & 2 & 3 & 2 & 1 & 0 & 8 \\
\hline 3 & Lks 3 & 2 & 3 & 2 & 3 & 1 & 11 \\
\hline 4 & Lks 4 & 2 & 3 & 2 & 3 & 1 & 11 \\
\hline 5 & Lks 5 & 2 & 3 & 2 & 3 & 1 & 11 \\
\hline \multicolumn{2}{|c|}{ Total } & 10 & 15 & 10 & 13 & 4 & \\
\hline \multicolumn{2}{|c|}{ Rerata } & 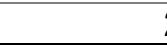 & & & & & \\
\hline
\end{tabular}

Data tersebut kemudian diubah ke dalam bentuk presentase untuk mengetahui frekuensi LKS pada setiap skor untuk setiap komponennya seperti pada tabel di bawah ini

Tabel 6. Presentasi skor Komponen Diagram Vee pada LKS SMA materi uji makanan

\begin{tabular}{|c|c|c|c|c|c|c|c|}
\hline \multirow[t]{2}{*}{ No } & \multirow[t]{2}{*}{ Komponen } & \multirow[t]{2}{*}{ Kisaran Skor } & \multicolumn{5}{|c|}{ Presentasi untuk Skor (\%) } \\
\hline & & & 1 & 2 & 3 & 4 & 5 \\
\hline 1 & Pertanyaan focus & $0-2$ & & & & & $100 \%$ \\
\hline 2 & Objek/Event & $0-3$ & & & & & $100 \%$ \\
\hline 3 & Langkah Prosedural & $0-2$ & & & & & $100 \%$ \\
\hline 4 & Catatan transformasi & $0-3$ & & & & $80 \%$ & \\
\hline 5 & Klaim Pengetahuan & $0-1$ & & & & $80 \%$ & \\
\hline
\end{tabular}

Data didapatkan berdasarkan analisis uji coba laboratorium yang diperoleh dari hasil analisis konseptual, analisis praktikal, dan analisis konstruksi pengetahuan kemudian dari analisis tujuan, pertanyaan fokus, langkah prosedural, objek/peristiwa, record/transformation, pertanyaan praktikum, dan knowledge claims. Lembar kerja siswa dianalisis dengan menggunakan dua instrumen. Instrumen pertama analisis berdasarkan instrument form analisis kegiatan laboratorium berupa tabel analisis 
konseptual, praktikal, dan konstruksi pengetahuan. Kemudian instrument kedua yaitu analisis berdasarkan Novak \& Gowin yaitu instrumen pertama berupa tabel analisis yang berisikan kisi-kisi penjabaran KD, empat indikator hasil penjabaran dari KD, dan kegiatan laboratorium yang dapat mungkin dilakukan dari indikator tersebut. Dalam melakukan analisis berbagai komponen diperlukan indikator untuk melihat kesesuaian berbagai komponen lembar kerja siswa dengan tuntutan KD. Sebelum digunakan untuk menganalisis, keseluruhan instrumen dilakukan judgement oleh dosen-dosen yang ahli dalam bidang pendidikan. Instrumen yang kedua berupa tabel analisis kesesuaian tujuan praktikum pada lembar kerja siswa. Instrumen ini digunakan untuk menilai ketergambaran tujuan pada langkah prosedural serta untuk melihat kesesuaian tujuan dengan indikator hasil penjabaran dari KD. Instrumen yang ketiga berupa tabel analisis pertanyaan fokus pada LKS yang mengacu kepada KD. Tabel analisis dikembangkan dari Novak \& Gowin (1985) dan digunakan untuk mengidentifikasi kesesuaian pertanyaan fokus dengan objek/peristiwa utama yang terbentuk pada kegiatan praktikum. Instrumen keempat berupa tabel analisis langkah prosedural pada LKS. Instrumen ini digunakan untuk melihat keterlaksanaan langkah prosedural dan kesesuaian objek/peristiwa yang muncul ketika kegiatan praktikum dilaksanakan serta dilihat relevansinya dengan tujuan praktikum dan indikator hasil penjabaran dari KD. Instrumen kelima, yaitu tabel analisis objek/ peristiwa lembar kerja siswa yang mengacu kepada KD. Tabel ini digunakan untuk melihat kesesuaian objek/peristiwa dengan langkah prosedural dan pertanyaan fokus pada LKS.

Pada instrumen berikutnya, terdapat tabel analisis pertanyaan praktikum pada lembar kerja siswa praktikum uji makanan. Instrumen keenam ini digunakan untuk melihat kesesuaian pertanyaan praktikum dengan data hasil praktikum dan tujuan praktikum terhadap ketercapaian konsep yang harus dimiliki siswa yang mengacu pada KD. Instrumen ketujuh, yaitu tabel analisis record/transformation dalam lembar kerja siswa pada praktikum uji makanan. Tabel ini berkaitan dengan keberadaan kegiatan pencatatan data hasil pengamatan, kegiatan transformasi dari catatan data hasil pengamatan, dan konsistensi kegiatan pencatatan serta transformasi dengan pertanyaan fokus. Pada instrumen kedelapan, tabel knowledge claims digunakan untuk melihat kesesuaian knowledge claims yang terbentuk dengan keberadaan arahan pertanyaan praktikum, kesesuaian knowledge claims dengan data hasil pengamatan, peristiwa yang dicatat dan ditransformasi, serta kesesuaian dengan pertanyaan fokus. Instrumen terakhir adalah bagan konsep yang disusun berdasarkan KD dari konsep pencernaan makanan khususnya zat makanan. Bagan konsep disusun untuk melihat keluasan materi yang terkandung dalam kegiatan praktikum dan kesesuaian knowledge claims yang terbentuk dengan tujuan praktikum. 


\section{Kesimpulan Analisis berdasarkan instrument form analisis kegiatan laboratorium}

1. Analisis Konseptual yaitu "LKS Uji Makanan yang dianalisis belum memuat konten dan melatih kompetensi (pengetahuan dan keterampilan) yang sesuai dengan tuntutan Kurikulum 2013"

2. Analisis Praktikal yaitu "LKS Uji Makanan yang dianalisis mampu memunculkan fenomena yang relevan dengan tujuan praktikum, tetapi belum relevan dengan tuntutan kompetensi dasar"

3. Alasan Perlu Direvisi, adalah:

- Mendukung pencapaian kompetensi dasar dalam kurikulum.

- Membantu peserta didik untuk mengonstruksi pengetahuannya kandungan bahan makanan.

- Sangat menarik untuk dilaksanakan dalam kegiatan pembelajaran.

- Memiliki relevansi dengan kehidupan sehari-hari peserta didik.

\section{Kesimpulan Analisis Konstruksi Pengetahuan berdasarkan instrument Novak \& Gowin}

Berdasarkan tabel hasil pengamatan di atas dengan menggnakan instrument Novak \& Gowin berkaitan dengan mengkonstruksi pengetahuan diperoleh hasil bahwa dari lima LKS yang di analisis hampir semua nilainya dibawah standar artinya LKS-LKS tersebut kurang bagus untuk mengkostruksi pengetahuan siswa hanya sekedar memferivikasi saja dan menjalankan langkah-langkah sesuai prosedur.

\section{KESIMPULAN}

Berdasarkan hasil analisis dan pembahasan mengenai berbagai komponen lembar kerja siswa diperoleh hasil bahwa lembar kerja siswa pada praktikum uji makanan yang dianalisis memiliki tujuan praktikum yang tidak relevan dengan hasil penjabaran dari KD. Tujuan praktikum pada lembar kerja siswa hanya sekedar mengetahui kandungan pada bahan makanan saja tanpa mengaitkan dengan kebutuhan energy setiap individu dan keamanan pangan. Dilihat dari komponen langkah prosedural, dari hasil analisis memiliki langkah prosedural yang dapat dikerjakan, kemunculan objek/peristiwanya dapat teramati, tidak relevan dengan tujuan praktikum, tidak sesuai dengan tuntutan Kompetensi Dasar. Langkah prosedural Procedur tidak mencapai tujuan dan tidak bisa menghadirkan fakta, sehingga objek/peristiwa yang muncul tidak dapat membentuk knowledge claims yang sesuai dengan tuntutan kurikulum.

\section{DAFTAR PUSTAKA}

Abraham, I \& Reiss, M. (2010). Effctive Practical Work In Primary Science: The Role Of Empathy. The Role of Emphaty. Primary Science 
Abrahams and R. Millar. (2008) Does practical work really work? a study of the effectiveness of practical work as a teaching and learning method in school science. Journal of Science Education, 30(14):1945-1969.

Akuma, F. V. (2017). A professional development framework for supporting inquirybased practical work in resource constrained classrooms (Doctoral dissertation, University of Pretoria).

Banu, S. (2011). The Role Of Practical Work in Teaching and Learning Physics at Secondary Level in Bangladesh. A thesis submitted to the University of Canterbury College of Education

Festile, (2017). The influence of Practical Work in the teaching and learning of acids, bases and neutrals in Natural Sciences. Masters in Science Education in the Science Learning Centre for Africa of the Faculty of Education at the University of the Western Cape.

Helliar, A \& Harrison, T (2011). A Wider Role for Technicians in Science Practical Work with School Students?. Volume 4 nomor 4.

Holman, S (2017). Good practical science. www.gatsby.org.uk bisa di akses di https://www.gatsby.org.uk/education/programmes/support-for-practical-sciencein-schools

Jokiranta, K. (2014). The Effectiveness of Practical Work in Science Education Bachelor's Thesis. University of Jyväskylä Department of Physics

Koirala, K (2019). Effectiveness of Practical Work on Students' Achievement in Science at Secondary Level in Gorkha District Nepal. Journal of Advances in Education Research, Vol. 4, No.4

Millar, R. (2004). The Role of practical work in the teaching and learning of science. Paper prepared for the Meeting: High School Science Laboratories: Role and Vision Departemen of Educational Studies University of York.

Millar, R. (2001). Teaching and learning science through practical work. Outline of talk given at Nordlab-DK Seminar, University of York, , Copenhagen.

Millar, R dan Abrahams, I. (2009). Practical work: making it more effective. SSR 91 (334)

Novak, J.D. 1990. Concept maps and Vee diagrams: two metacognitive tools to facilitate meaningful learning. Instructional Science 19(1), pp. 29-52

Novak, J.D., Gowin, D. B. (1984). Learning How to Learn. New York: CAMBRIDGE UNIVERSITY PRESS

Philip, J. M. D., \& Taber, K. S. (2015). Separating "Inquiry Questions" and "Techniques" to Help Learners Move between the How and the Why of Biology Practical Work. Journal of Biological Education, 50(2), 207226. doi:10.1080/00219266.2015.1058840

Rustaman, N. 2005. Strategi Belajar Mengajar Biologi. Malang: UM Press.

Rustaman, A., \& Wulan, A. (2007). Kegiatan Laboratorium dalam Pembelajaran Biologi. 
Siti, S (2013). Teachers' purposes and practices in implementing practical work at the lower secondary school level. Procedia - Social and Behavioral Sciences 116 (2014) $1016-1020$

Supriatno, B. (2007). Profil lembar kegiatan biologi siswa sekolah menengah. dalam Proseding Seminar Nasional Jurusan Pendidikan Biologi. Bandung: Universitas Pendidikan Indonesia.

Supriatno, B. (2009). Uji langkah kerja laboratorium biologi sekolah. dalam Proseding Seminar Nasional Jurusan Pendidikan Biologi. Bandung: Universitas Pendidikan Indonesia.

Supriatno, B. (2013). Pengembangan Program Perkuliahan Pengembangan Praktikum Biologi Sekolah Berbasis Ancorb Untuk Mengembangkan Kemampuan Merancang Dan Mengembangkan Lembar kerja siswa. (Disertasi). Sekolah pascasarjana Universitas pendidikan Indonesia, Bandung.

Supriatno, B. (2018). Praktikum untuk Membangun Kompetensi. Proceeding Biology Education Conference Volume 15, Nomor 1 Halaman 1-18.

Sukmadinata, N. S. (2011). Metode Penelitian Pendidikan. Bandung: PT Remaja Rosdakarya.

Sharpe, R., \& Abrahams, I. (2019). Secondary school students' attitudes to practical work in biology, chemistry and physics in England. Research in Science \& Technological Education, 1-21. doi:10.1080/02635143.2019.1597696

Society of Biology. (2010)Practical Biology Position Statement. The Importance of Practical Biology: from School to Higher Education.

Sriyati, S \& Rahmayanti, E (2013) Pengembangan Asesmen Pembelajaran Sesuai Tuntutan Kurikulum 2013 Pada Materi Fotosintesis di SMP. Seminar Nasional XI Pendidikan Biologi FKIP UNS.

UK Centre for Bioscience The Higher Education Academy. (2010) Student Short Guide Making the Most of Practical WorkRoom 9.15 Worsley Building University of Leeds, Leeds, LS2 9JT Tel / Fax: 01133433001 / 5894 Email: heabioscience@leeds.ac.uk www.bioscience.heacademy.ac.uk.

Zubaidah, S. (2019). Memberdayakan Keterampilan Abad Ke-21 melalui Pembelajaran Berbasis Proyek1. In Seminar Nasional Nasional Pendidikan Biologi. 